\title{
Hoe implementeer je preventief medische adviezen?
}

\author{
H.F. van der Molen • J.K. Sluiter • C.T.J. Hulshof • J. \\ C. van Duivenbooden • P. Vink • M.H.W. Frings-Dresen
}

Keywords implementatie - preventief medisch advies . bedrijfsgezondheidszorg

Eén van de kerntaken van de bedrijfarts is het verstrekken van individuele en collectieve preventief medische adviezen aan werknemers en werkgevers. ${ }^{1}$ Echter het is nog maar de vraag in hoeverre de adviezen werkzaam zijn en in hoeverre deze adviezen ook in de praktijk (kunnen) worden opgevolgd. Adviezen worden veelal gegeven om gedragsverandering bij de werknemers en/ of werkgevers te bewerkstelligen.

1. Implementatie richt zich op de procesmatige en planmatige invoering van maatregelen.

2. Selecteer effectieve maatregelen.

3. Informatie alleen leidt niet tot gedragsverandering.

Voordat adviezen leiden tot de gewenste gedragsveranderingen moeten vaak een aantal verschillende maatregelen worden geïmplementeerd, zowel op individueel, bedrijf- of brancheniveau. Casestudies, (gerandomiseerde) gecontroleerde onderzoeken en systematische reviews zijn bouwstenen waarop de wijze van het implementeren van maatregelen kan worden gebaseerd. ${ }^{2}$ Wetenschappelijke interventieonderzoeken zijn bekende onderzoeksvormen om de effectiviteit van maatregelen te onderzoeken, maar de maatregelen dienen daarna nog in de praktijk te worden geïmplementeerd. In toenemende mate wordt in praktijk én wetenschap het belang onderkend om via een stapsgewijze aanpak tot de uitvoering en evaluatie van de implementatie van maatregelen te komen. ${ }^{3,4}$

Implementatie richt zich primair op de procesmatige en planmatige invoering van maatregelen van bewezen waarde met als doel dat deze een structurele plaats krijgen in het beroepsmatig handelen of in het functioneren

van organisatie( s). ${ }^{5}$ Bij implementatie(onderzoek) staat de implementatiestrategie centraal, de werkzaamheid van de maatregelen is dan reeds vastgesteld dan wel aangenomen. In deze definitie is implementatie de proces- en planmatige invoering van effectief gebleken maatregelen van eerder onderzoek.

Het doel van dit praktijkartikel is tweeledig:

a. beschrijving van een vijfstappenplan voor de implementatie van preventief medische adviezen;en

b. beschrijving van voorbeelden van methodieken en resultaten voor elk van de vijf stappen.

Het stappenplan en de voorbeelden zijn ontleend aan de onderzoeken en aanbevelingen uit het prijswinnende proefschrift van de Burgerpenning 2007 $7^{6,7}$ aangevuld met recente implementatieartikelen uit de wetenschappelijke literatuur.

\section{Stappenplan implementatie}

Op welke wijze preventief medische adviezen effectief kunnen worden geïmplementeerd is niet eenduidig te beantwoorden. Wel kan met behulp van een stappenplan het implementatieproces worden gestructureerd waarmee de te nemen maatregelen en de bijbehorende implementatiestrategieën kunnen worden geselecteerd en geëvalueerd. Onderstaand vijfstappenplan (zie tabel 1) is gebaseerd op implementatieonderzoek uit de gezondheidszorg. ${ }^{4}$

Tabel 1 Vijfstappenplan voor implementatie van preventief medische adviezen

- Selecteer effectieve maatregelen als invulling van het preventief medisch advies

- Analyseer sociale \& organisatorische context voor implementatiebelemmeringen 
- Selecteer effectieve implementatiestrategieën om belemmeringen op te heffen

- Stimuleer de invoering van maatregelen door 'goalsetting', planning en implementatiestrategieën

- Evalueer de implementatie van de maatregelen

Stap 1: Selecteer effectieve maatregelen als invulling van het preventief medisch advies

Het doel van de eerste stap is het selecteren van (potentieel) effectieve maatregelen om de expositie aan risicofactoren te verminderen en gezondheidsproblemen te voorkomen. Daartoe kan de bedrijfsarts verschillende informatiebronnen raadplegen zoals collega's, experts, brancheorganisaties en literatuur. De Cochrane Library (systematische reviews) en PubMed bevatten wetenschappelijke literatuur over de effectiviteit van werkgebonden interventies. De informatievraag kan met behulp van de PICO-methodiek worden getransformeerd naar een beantwoordbare vraag en corresponderende zoekstrategie. De populatie $(\mathrm{P})$, de interventieconditie (I), de controleconditie $(\mathrm{C})$ en de onderzoeksuitkomst (O) moeten worden gedefinieerd waarmee vervolgens systematisch in de wetenschappelijke databases kan worden gezocht.

\section{Voorbeeld}

Stel dat meer informatie gewenst is om effectieve maatregelen te vinden die de lichamelijke belasting bij metselaars kan verminderen ter preventie van klachten aan het bewegingsapparaat. De te beantwoorden onderzoeksvraag zou kunnen luiden: 'Wat zijn bij metselaars (P) effectieve maatregelen (I), ten opzichte van de gangbare werkmethode $(\mathrm{C})$, om de lichamelijke belasting (O) te verlagen?'. Als in PubMed een zoekstrategie wordt gemaakt van (bricklay* AND intervention AND physical work) worden drie resultaten getoond waaronder een gecontroleerd onderzoek naar het effect van werkhoogteaanpassing en mechanisatie op de fysieke arbeidsbelasting en klachten aan het houdingsen bewegingsapparaat bij metselaars en opperlieden. ${ }^{8}$ Daaruit is gebleken dat de frequentie ( 920 keer minder) en duur (42 minuten minder) van rompbuiging van meer dan $60^{\circ}$ op een werkdag significant dalen door opgehoogd metselen. Bij opperlieden is ook een significante afname van de fysieke taakeisen te zien als zij een kraan voor het mechanische transport van stenen en mortel gebruiken. Beide ergonomische werkmethoden verminderden het ervaren ongemak in de lage rug bij zowel de metselaars als de opperlieden.
Stap 2: Analyseer sociale \& organisatorische context voor implementatiebelemmeringen

Het doel van de tweede stap is het inventariseren van belemmerende (c.q. bevorderende) factoren van alle actorgroepen die zijn betrokken bij de implementatie van de maatregelen, zodat ook gericht kan worden geïntervenieerd op deze belemmeringen. Er kunnen vier groepen van actoren worden onderscheiden:5,9 gebruikers, invoerders, beslissers en helpers van de te nemen maatregelen. Gebruikers zullen de maatregelen moeten gaan opvolgen, bijvoorbeeld de werknemer die mechanische hulpmiddelen moet gaan gebruiken bij het transporteren van metselstenen. Invoerders zullen de voorwaarden moeten scheppen om de adviezen te kunnen opvolgen, bijvoorbeeld de direct leidinggevende. Beslissers besluiten over de daadwerkelijke invoering van adviezen, bijvoorbeeld de werkgever over de aanschaf van mechanische hulpmiddelen. Helpers zijn actoren buiten het bedrijf die de implementatie van maatregelen kunnen stimuleren zoals werkgeversorganisaties, vakbonden, branche organisaties, UWV, re-integratiebedrijven, onderzoeksinstituten of de arbeidsinspectie.

Voor de implementatie van ergonomische hulpmiddelen in de bouw zijn voor elke actor zeven fasen van het veranderingsproces ${ }^{5}$ gedefinieerd:

1. weten (bewustwording van de ergonomische hulpmiddelen);

2. begrijpen (begrijpen wat de hulpmiddelen beogen);

3. willen (gemotiveerd zijn om met de hulpmiddelen te gaan werken);

4. besluiten (beslissen dat hulpmiddelen worden aangeschaft en gebruikt);

5. kunnen (voorwaarden creëren die gebruik hulpmiddelen mogelijk maken);

6. invoeren (ervaring opdoen met de hulpmiddelen);

7. gebruiken (blijven gebruiken van de hulpmiddelen).

Belemmeringen in dit veranderingsproces dienen voor alle relevante actoren(groepen) te worden geanalyseerd. Deze analyse kan via verschillende methodieken in kaart worden gebracht, bijvoorbeeld door interviews, vragenlijsten of expertbeoordelingen, bij de werknemers (gebruikers), leidinggevende (invoerder), werkgever (beslisser) en overige relevante actoren (helpers) voor het veranderingsproces. Immers het uiteindelijke doel van de implementatie is eventuele belemmeringen op te heffen om zodoende de gewenste gedragsverandering van de werknemers en de overige actoren - meestal de direct leidinggevende en de werkgevers - te bewerkstelligen. 


\section{Voorbeeld}

In een kwalitatief, verkennend onderzoek werden vijf gedragsveranderingsfasen bij twee actorgroepen onderzocht aan het begin van een implementatieproces van vier ergonomische hulpmiddelen bij metselteams. ${ }^{6}$ Gestructureerde interviews werden afgenomen bij een groep werkgevers/planners $(n=11)$ en een groep voorlieden/metselaars $(n=9)$ van negen metselbedrijven om de status van de eerste vijf gedragsveranderingsfasen (weten, begrijpen, willen, besluiten, kunnen) vast te stellen. Werkgevers en werknemers zijn belangrijk bij het nemen van de daadwerkelijke beslissing om ergonomische hulpmiddelen bij het metselen en opperen in te voeren. Uit de interviews bleek het aantal doorlopen gedragsveranderingsfasen voor ieder ergonomisch hulpmiddel aanzienlijk te verschillen tussen individuen, en actorgroepen zoals bedrijven. Gebrek aan kennis over de risico's van diep bukken ('weten') en organisatorische knelpunten ('kunnen'), zoals afspraken met de hoofdaannemer en steigerbouwer over de ophoging van metselmaterialen, vormden de grootste belemmeringen.

Stap 3: Selecteer effectieve implementatiestrategieën om belemmeringen op te heffen

Het doel van de derde stap is de keuze van effectieve implementatiestrategieën voor de invoering van de maatregelen. Een blauwdruk voor een optimale implementatiestrategie hangt onder andere af van een goede contextanalyse (zie stap 2), waaruit moet blijken bij welke actoren en welke fasen belemmeringen voor de implementatie bestaan.

Tenminste vijf verschillende implementatiestrategieën ${ }^{5,10}$ kunnen worden onderscheiden die op de geanalyseerde belemmeringen kunnen interveniëren:

1. informatieve strategieën voor het opheffen van belemmeringen in kennis zoals bijeenkomsten of brochures;

2. educatieve strategieën voor het opheffen van belemmeringen in begrip, motivatie en vaardigheden zoals trainingen;

3. dwingende strategieën voor het opheffen van belemmeringen in het uiteindelijk gebruik van maatregelen zoals werkplekcontroles;

4. overtuigende strategieën voor het opheffen van belemmeringen in motivatie en besluit tot gedragsverandering zoals demonstratie- of proefprojecten; en

5. faciliterende strategieën voor het opheffen van belemmeringen in de voorwaardenfase zoals belastingvoor- deel bij het aanschaffen van hulpmiddelen of gratis verstrekking van de hulpmiddelen.

De contextanalyse - eventueel aangevuld met het raadplegen van de wetenschappelijke literatuur - vormt de basis voor de keuze van de uiteindelijke implementatiestrategie(ën).

\section{Voorbeeld}

Uit een systematisch literatuuronderzoek naar vermindering van de fysieke arbeidsbelasting bleek dat 26 veldonderzoeken het effect van implementatiestrategieën op verschillende procesmaten (bewustwording, attitude, in staat zijn om het gewenste gedrag uit te kunnen voeren en het gewenste gedrag zelf) hadden onderzocht. ${ }^{6}$ In deze onderzoeken werden veranderingen in attitude en gedrag gerapporteerd, als:

| eerst ervaring was opgedaan met de voorgestelde maatregelen (educatieve strategieën);

| werknemers betrokken waren bij de keuze en invoering van de maatregelen (faciliterende strategieën);

I de beschikbaarheid van maatregelen werd geregeld door de werkgever (faciliterende strategieën) of afgedwongen door de arbeidsinspectie (dwingende strategieën).

Uit enkele onderzoeken bleek dat als alleen informatiestrategieën werden toegepast de beoogde gedragsveranderingen niet werden bereikt. De enige twee gecontroleerde longitudinale onderzoeken lieten zien dat vooral gecombineerde implementatiestrategieën - waaronder faciliterende en educatieve - ervoor zorgden dat de fysieke arbeidsbelasting en klachten aan het houdingen bewegingsapparaat verminderden.

Stap 4: Stimuleer de invoering van maatregelen door 'goalsetting', planning en implementatiestrategieën

Het doel van de vierde stap is de stimulering van de implementatie van de maatregelen aan de hand van doelstellingen, planning en implementatiestrategieën. In de praktijk zullen er vaak meer implementatiestrategieën naast elkaar gebruikt moeten worden om de invoering van maatregelen te bewerkstelligen. Specifieke, meetbare en haalbare doelen alsmede een realistische tijdplanning waarin de implementatiestrategieën worden uitgevoerd kunnen behulpzaam zijn bij de invoering van de maatregelen. Specifieke doelen zijn eenduidig en representeren de voorgestelde (gedrags)verandering. Meetbare doelen veronderstellen betrouwbare en valide uitkomstmaten met adequate meetstrategieën. Een realistische tijdsplanning van de maatregelen (resultaten uit stap 1) en de 
bijbehorende implementatiestrategieën (resultaten uit de stappen 2, 3 en 4) verhogen de kans dat de gestelde doelen gehaald worden.

\section{Voorbeeld}

In een Deens implementatieonderzoek ${ }^{11}$ zijn voor elk van de zeven gedefinieerde gedragveranderingsfasen (zie stap 2) doelen en implementatiestrategieën geselecteerd voor de invoering van hulpmiddelen om geknield werken bij vloerenleggers te voorkomen, namelijk:

1. informeren van werkgevers en vloerenleggers over nieuwe hulpmiddelen (weten; informerende strategie);

2. informeren van vloerenleggers over gezondheidswinst van het werken met nieuwe hulpmiddelen (begrijpen; informerende strategie);

3. hulpmiddelen laten zien en de vloerenleggers overtuigen om ze te gebruiken (willen; overtuigende strategie);

4. vloerenleggers de hulpmiddelen gratis ter beschikking stellen indien ze deelnemen aan een tweedaagse training (besluiten; faciliterende strategie);

5. tweedaagse training voor gebruik hulpmiddelen met een ervaren vloerenlegger als trainer (kunnen; educatieve strategie);

6. ervaring opdoen met de hulpmiddelen (invoeren; educatieve strategie); en

7. voorwaarden scheppen voor blijvend gebruik van de hulpmiddelen met ondersteuning door brancheorganisaties (gebruiken; faciliterende strategie).

De implementatiestrategieën werden binnen één jaar uitgevoerd. Na de trainingsperiode gebruikte $43 \%$ van de vloerenleggers de hulpmiddelen. Van de vloerenleggers die hulpmiddelen gebruikten, gaf 24\% (wekelijks gebruik) tot $41 \%$ (dagelijks gebruik) aan minder knieklachten te ervaren.

Stap 5: Evalueer de implementatie van de maatregelen

Het doel van de vijfde stap is de evaluatie van het implementatietraject. Het is belangrijk om het implementatieproces bij alle actoren te blijven volgen en eventueel bij te stellen aan de hand van vooraf opgestelde prestatie- en procesindicatoren. De drie te beantwoorden hoofdvragen zijn:

- in welke mate worden de implementatiestrategieën uitgevoerd?

- in welke mate worden de maatregelen toegepast? en

- in welke mate worden de (beoogde) gezondheidseffecten behaald?

\section{Voorbeeld}

In het kader van de Arboconvenant Bouw werden bouwbedrijven gedurende 2000 tot 2005 gestimuleerd om ergonomische maatregelen in te voeren, terwijl de werknemers werden gestimuleerd om de maatregelen daadwerkelijk toe te passen om daarmee de belasting door handmatig tillen en bukken in het werk te verminderen. ${ }^{12}$ In totaal 44 tot $53 \%$ van de werknemers gaf aan geen informatie over tilrisico's en maatregelen te hebben ontvangen. Stratenmakers waren het best geïnformeerd over de tilrisico's en maatregelen door vooral schriftelijke informatie (36\%) en bijeenkomsten (24\%). In totaal $59 \%$ van de timmerlieden, $63 \%$ van de metselaars en $54 \%$ van de stratenmakers was bekend met de beleidsregel 'Tillen op bouwplaatsen'. De bekendheid met de inhoud van de beleidsregel lag veel hoger (80-90\%). Na 4,5 jaar werden 20 van de 53 ergonomische maatregelen significant vaker gebruikt. Alleen bij de metselaars werd $10 \%$ reductie van rugklachten behaald.

\section{Beschouwing}

Het gepresenteerde stappenplan is een voorbeeld waarmee preventieve adviezen in de bedrijfsgezondheidszorg, en in het bijzonder in de bouw, geïmplementeerd kunnen worden. Het aantal te nemen stappen en de volgorde van deze stappen zal afhangen van de maatregelen en de sociaal organisatorische context waarbinnen de maatregelen moeten worden geïmplementeerd. Het stappenplan is een hulpmiddel voor het preventief medisch onderzoek waarmee adviezen, zowel ter preventie van arbeidsrisico's als gezondheidsklachten, mogelijk ook effectief kunnen worden geïmplementeerd.

\section{Literatuur}

Competentieprofiel bedrijfsgeneeskunde. Utrecht: NVAB, 2006.

Campbell M, Fitzpatrick R, Haines A, et al. Framework for design and evaluation of complex interventions to improve health. BMJ 2000; 321: 694-696.

Grol R. Beliefs and evidence in changing clinical practice. BMJ 1997; 315: 418-421.

Introductie basisprincipes implementatie. Nationaal Instituut voor Gezondheidsbevordering en Ziektepreventie, 2001.

Met het oog op toepassing. Beleidskader Implementatie $1997-$ 1999, samenvatting. Zorg Onderzoek Nederland, 1997.

Molen HF van der. Evidence-based implementation of ergonomic measures in construction work. Proefschrift, Universiteit van Amsterdam, 2005.

Judicium Burgerpenning 2007. Utrecht: NVAB, 2007. 
Molen HF van der, Grouwstra R, Kuijer PPFM, et al. Efficacy of adjusting working height and mechanizing of transport on physical work demands and local discomfort in construction work. Ergonomics 2004; 47(7): 772-783.

Rogers E. Diffusion of innovations. New York: The Free Press, 1995, 4th edition.

Hulscher M, Wensing M, Grol R. Effectieve implementatie: theorieën en strategieën. Den Haag: ZON/WOK, 2000.
Jensen LK, Friche C. Effects of training to implement new tools and working methods to reduce knee load in floor layers. Appl Ergon 2007; 38: 655-665.

Molen HF van der, Sluiter JK, Frings-Dresen MHW. Evaluatie Arboconvenant: beïnvloeding en gevolgen van lichamelijke belasting bij timmerlieden, metselaars en stratenmakers. Amsterdam: Coronel Instituut, 2006, rapportnummer 5-08. 